\title{
Oracular Functioning and Architecture of Five Ancient Apollo Temples Through Archaeoastronomy: Novel Approach and Interpretation
}

\author{
Belen Martin Castro ${ }^{1}$ Ioannis Liritzis ${ }^{1,2}$. \\ Anne Nyquist ${ }^{3}$
}

\begin{abstract}
Five temples of Apollo on Mainland Greece and Ancient Ionia (Asia Minor), namely Delphi, Didyma, Hierapolis, Delos and Rhodes, have been examined regarding their functioning through astronomical orientation. Recent research has shown that the rise, setting, orbit and observation of certain constellations in the celestial sphere, as well as the solar stands, can be directly related to the architecture of the temple, i.e. construction, orientation, and keeping a calendar of the most important Apollonian oracular temple at Delphi. Here this lunar-solar-stellar configuration has been applied to other significant temples of Apollo. It is shown that at Didyma, Hierapolis and Delphi, the celestial pattern, as well as the landscape, local geology and architecture are similar, but different in temples without oracular function (Delos and Rhodes). Measurements were carried out by in situ readings and by Google Map tools.
\end{abstract}

\section{Introduction}

The architectural significance that is reinforced by astronomical horizon markers has been a matter of much research and ongoing results are made available in academic literature. Archaeoastronomical research around the world has shown that in planning urban sites and building structures, traditional historic and prehistoric cultures have incorporated astronomical alignments of calendrical or sacred ritual

$\square$ Ioannis Liritzis

liritzis@rhodes.aegean.gr

1 Laboratory of Archaeometry, Department of Mediterranean Studies, University of the Aegean, Rhodes 85100, Greece

2 King Saud University, Riyadh, Saudi Arabia

3 Institute of Archaeology, Conservation and History, Faculty of Humanities, University of Oslo, Postbox 1008, Blindern, 0315 Oslo, Norway 
importance. Alignments to the solstices, the equinoxes, and to the major standstills of the moon and bright planets have been demonstrated or suggested, while stellar alignments have also been shown to have been important for some societies (Magli 2009, 2013; Ruggles 2014).

Astronomy, landscape and symbolism in field studies concerning orientation has been reported for ancient Egyptian temples, for Incas, Yucatan, megalithic structures in France (Carnac) and Britain (Stonehenge, Newgrange), the Forbidden City in Beijing, and across the whole face of the earth are found mysterious ruins of ancient monuments with astronomical significance. They are architecturally arranged to demonstrate their cosmology, that is, are laid out to follow cosmic order, or as time keepers, and in general their architecture provides a new key for understanding the meaning and function of those buildings (Belmonte and Shaltout 2009; Aveni 2001a, b; Iwaniszewski 2001; Magli 2009; Krupp 2003).

The astroscape (or skyscape) and the landscape over Delphi indicates that the orientation of the temple aims to follow stellar movements. The Delphi temple of Apollo (the Pythian) was the most famous oracle center in the ancient world (Flacelier, 1938; Fontenrose 1980), with its combined tectonic features, hydrocarbon gases and springs (Leclerc 2008). Keeping a calendar for its functioning was extremely important. The apparent orbit of Lyra and Cygnus (the swan) over the Delphic night sky has been shown to correlate with the timing of the mythological retreat of Apollo to northern lands during winter and his return in spring time (Fig. 1) (Liritzis and Castro 2013).

Five important Apollo temples in the Aegean-Delphi, Delos, Rhodes, Didyma and Hierapolis (Fig. 2) - are studied for their intentional orientation connected to celestial bodies, and for the god's properties practiced at each particular city (Liritzis and Castro 2013). The choice of these Temples is due to (a) historical sources with similar functioning of Oracles to Apollo, (b) to contrast Apollonian Temples with non oracular function, (c) an interesting comparison between in situ and remote values was made and critically discussed; the Rhodes, Delos, and Delphi Temples have been well studied archaeologically and in situ archaeoastronomically by us and others (see Table 1); for Didyma only one early citation and for Hierapolis no readings are available. Concerning Bassae (the Epicurian Apollo) this temple though important had no known oracular functioning, while its $\mathrm{N}-\mathrm{S}$ orientation has been studied elsewhere (Liritzis and Vasiliou 2003) and other Apollonian Temples are already studied in Liritzis and Vasiliou (2002).

The mythological background that related Apollo to these two constellations tells us about the myth of the yearly trip of the god to the land of the Hyperboreans (northern lands or heperpontean $=$ overseas (Bridgman 2004, pp 24-57; Alcaeus Frag. 307.1(c); Lobel and Page in Himerius, Oration 14.10 ff taken from http:// www.loebclassics.com/view/alcaeus-fragments/1982/pb_LCL142.355.xml).

As Apollo is associated with light (and enlightenment), and with the sun, this could represent the god himself "arriving" and "leaving" with his lyra and swans. After this departure none of the constellations can be seen for the winter period given that the mountain climate during winter is also an important factor that can prevent the observation of the night sky. This configuration occurred from $\sim 1200$ $\mathrm{BC}$ to $\sim 300 \mathrm{AD}$. 


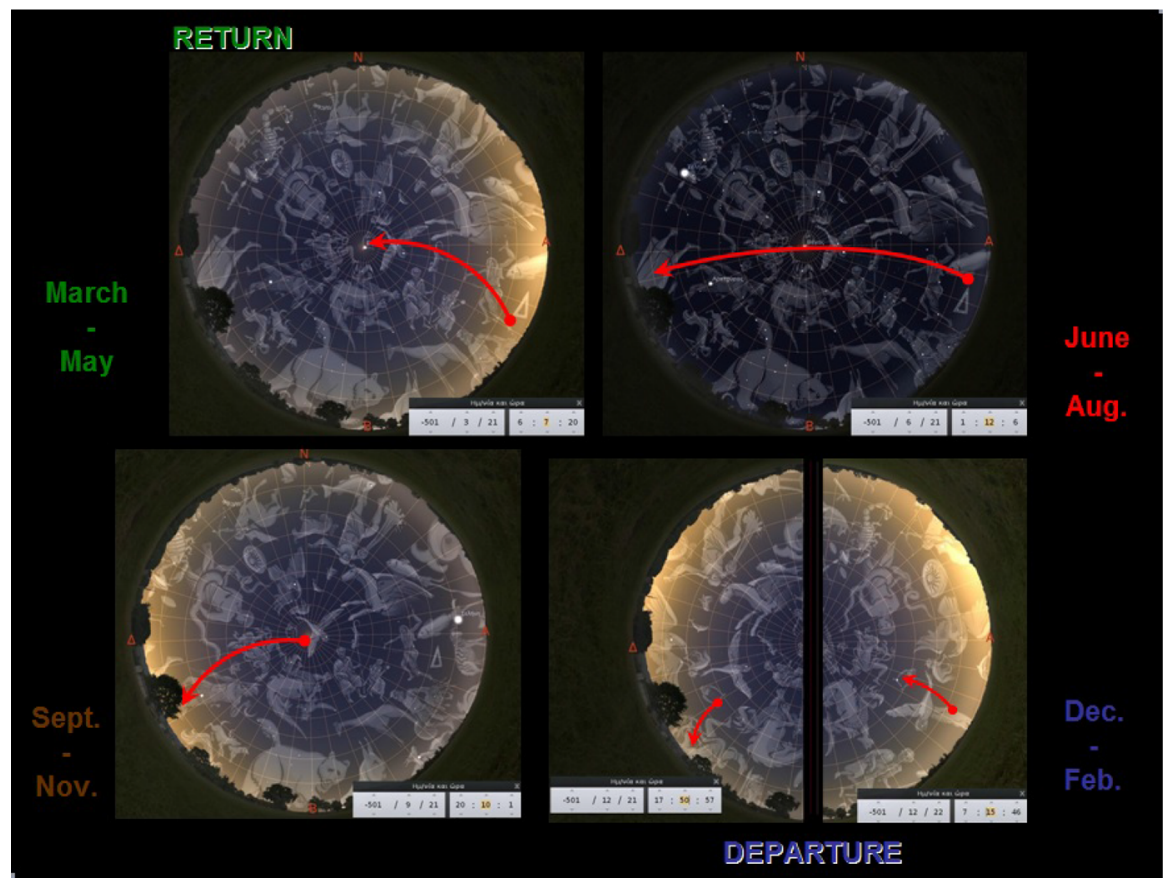

Fig. 1 The seasonal appearance and "path" (in red) of the constellations over the Temple of Apollo at Delphi. Note the little duration in minutes in their appearance at dawn and setting during wintertime, weather permitting, gradually staying longer towards spring equinox that reaches zenith at dawn (after Liritzis and Castro 2013) (colour figure online)

To the Greeks, the dates upon which Lyra and Cygnus were located at certain positions in the sky just before sunrise or at sunset were particularly important. Although the heliacal rising or setting normally refers to stars, and Lyra and Cygnus are constellations with several stars occupying large areas of the sky, the exact rising, setting or zenith (right above the Temple) positions of their brightest stars served as visual sky markers in relation to the Temple of Delphi's orientation.

Plutarch himself, who had served at the temple and had been initiated at the Delphic mysteries, also notices the relevant role of weather in the functions of the temple and the calculation of the most correct date for the beginning of the period of the omens of the Pythia (Plutarch, Moralia VI). ${ }^{1}$ It is possible that Delphi functioned as what may resemble an astronomical 'observatory' following a solarlunar-astral calendar (saving the phenomena of the seasons) that was important in the functioning of the oracle, because choosing the right dates for the omens was a

\footnotetext{
${ }^{1}$ See, Loeb Classical Library, 1936. vol. V, pp 347-501. On the letter E at Delphi, (de E apud Delphos), On the Oracle of the Pythia (de Pythiae oraculis) and On the obsolescence of the oracles (de Defectu Oraculorum). In general the dialogues of Plutarch at his Moralia are full of references to Delphi. In another dialogue On the principle of cold (De primo frigido) he states that winter can be a hard (even dangerous) time to visit Delphi. Yet the main details about the oracle are given in the three dialogs of the Moralia VI.
} 


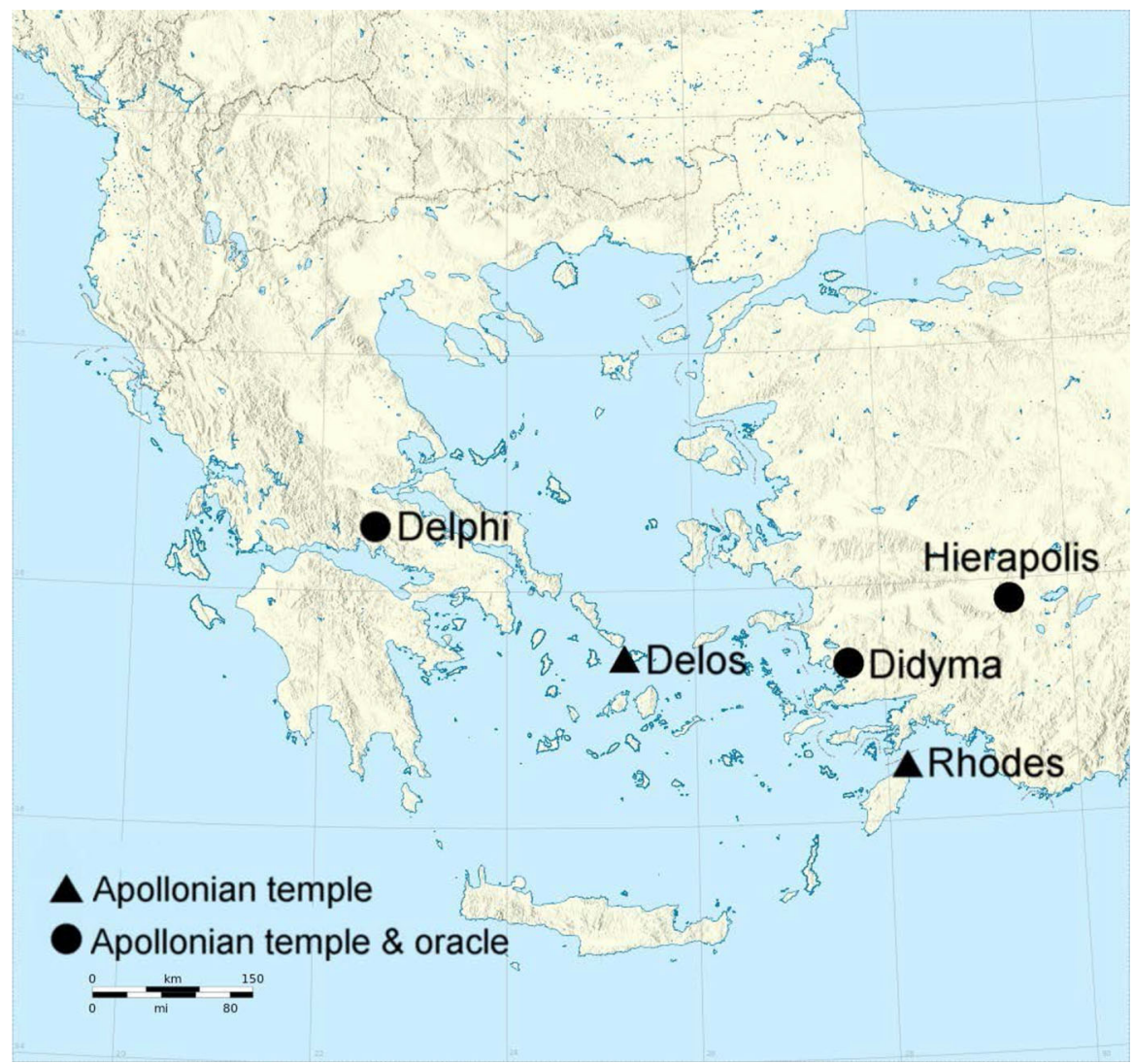

Fig. 2 Aegean region with position of Apollonian temples

fundamental part of the whole ceremonial (Liritzis and Castro 2013). This claim is based on the combined involvement of the positions of sun, moon and stars.

Is this important "phenomenon" for the calculation of the seasons exclusive for Delphi or can it be seen in other Apollonian temples, as well? To check this hypothesis, measurements at different Apollonian temples were taken that belong to different geographical points and were built at different periods so that we can have a broader image of the skyscape configuration and landscape architecture related to the temples and sanctuaries of Apollo.

The historical bases justifying the present study are the numerous ancient reports on oracles of Apollo and the repeated proof of the intentional construction and orientation of ancient temples. The orientation of buildings in the ancient Classical world has been attributed to celestial bodies and sunrise at one of the four solar stands (two equinoxes and two solstices) by renowned scholars from the 19th to the early 20th century (Penrose 1893; Nissen 1906-10; Dinsmoor 1939). More recent researchers have continued this work (Shaw 1977; Henriksson and Blomberg 1996, 2011; Papathanassiou and Hoskin 1994; Aveni and Ammerman 2001; Liritzis and Vassiliou 2003). Although astronomical targets may have been only one among 


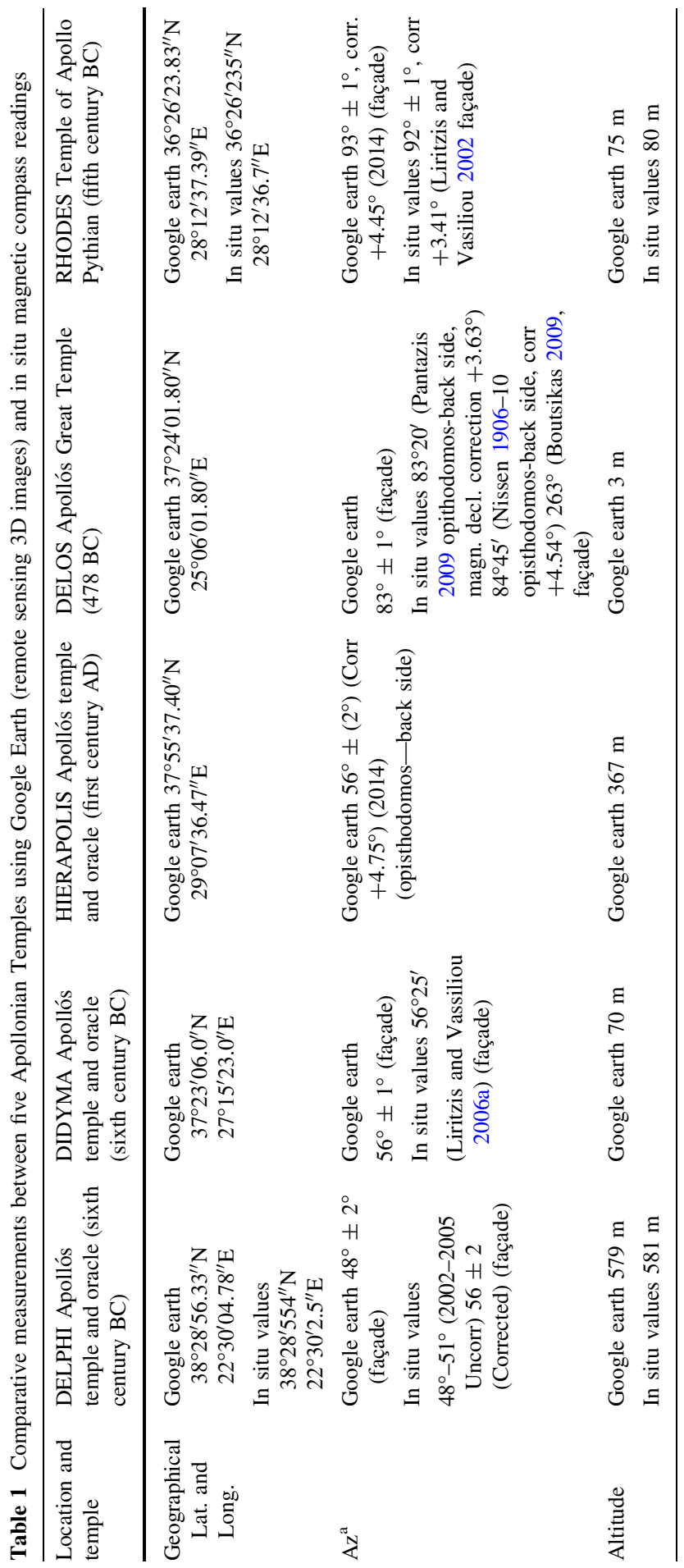




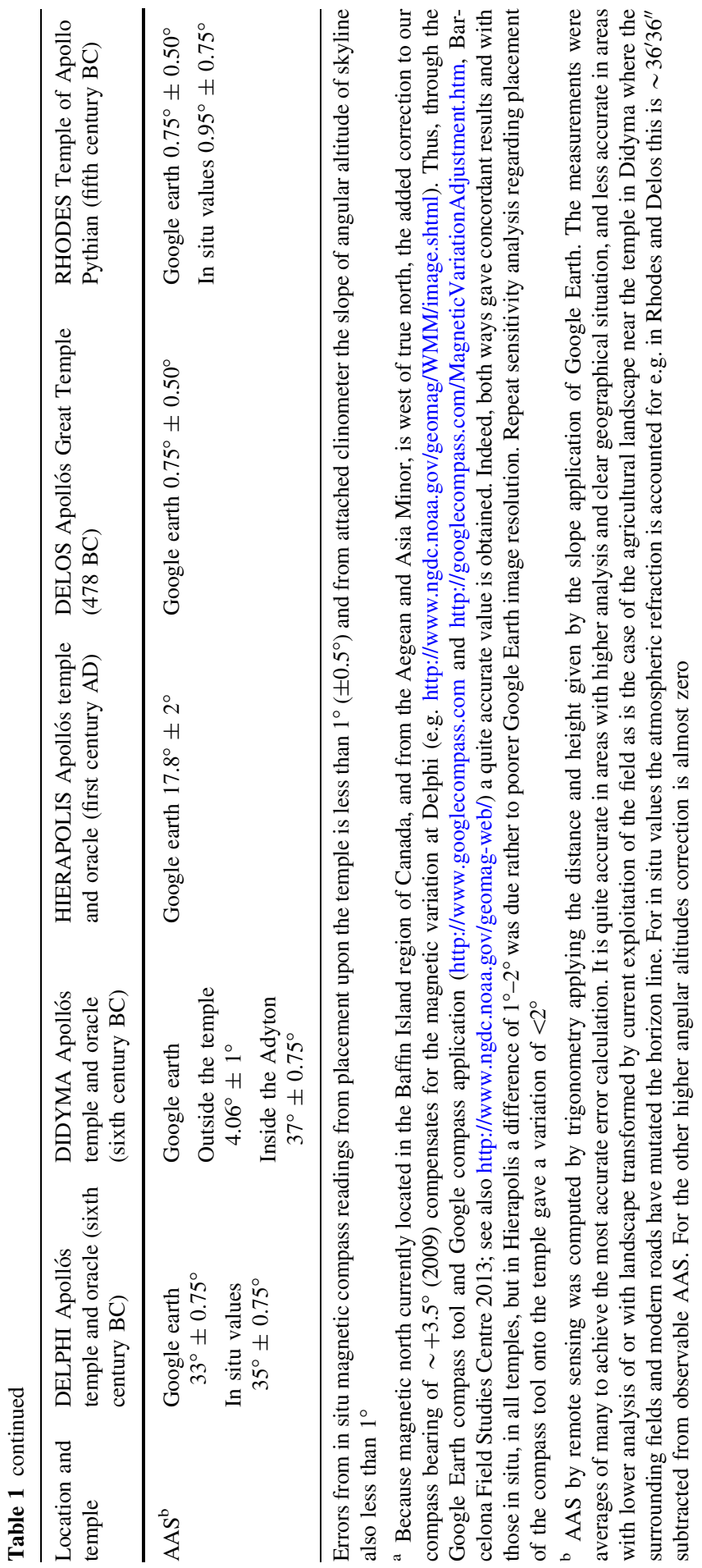


several factors that determined the orientation of such ancient buildings, arguments drawn from ancient literature support contemporary research that point to intentional architectural orientation towards a celestial phenomenon. The architectural aspects of the work refer to (a) the manner in which to construct the temple structure with intentional orientation, (b) the connection of architecture with light propagation, and (c) the height of the temple at Didyma.

\section{Measurements}

Measurements of azimuth, latitude, and angular altitude of horizon have been taken either in situ by portable GPS (Garmin GPS III), and a magnetic compass/clinometer (Meridian, MG-3101), and then compared with Google Earth maps or just by applying Google maps where the in situ measurements were not possible (a sort of remote sensing tool or virtual fieldwork elaboration). The software applied for the calculation of the altitude of sun or star for given azimuths in the ancient sky was Stellarium version 0.12.4 and rechecked with SkyMap Pro Version 10. The compass had been checked against a calibrated one at the company's premises and with a theodolite. Around ten compass readings were taken and the average was calculated. The geological environment of the temples in this study is void of magnetic materials and is mainly limestone. In addition, the astronomical declination $(\delta)$ of a horizon point and the corresponding day of the year of sunrise were calculated using specially developed software (STARDEC and SUNDAY) based upon appropriate formulas (Ruggles 1999) and on star catalogues by Hawkins and Rosenthal (1967); a method which has been used elsewhere (Liritzis and Vassiliou 2002, 2006b).

Declination corrections included (a) local magnetic declination, (b) refraction, and (c) extinction. Magnetic declination correction (the difference between true and magnetic north) was made based on World Magnetic Models by NOAA (see: http:// www.ngdc.noaa.gov/geomag-web/). At any rate errors in declination from Az errors $\left(\right.$ say $\pm 1^{\circ}$ ) give a fraction of a degree in declination (Liritzis and Vassiliou 2002, 2003). Our research was thus conducted by means of satellite images, i.e. in a remote sensing manner, for Azimuth (Az) and horizon altitude or Angular Altitude of Skyline (AAS) via Google Earth (version 7.1.2.2041) and its different applications for slope calculation, and, compass tools. Concerning the azimuth values, errors involved in compass were at the level of $\pm 0.5^{\circ}$ while for AAS angles a $\pm 0.5^{\circ}$ uncertainty. The $\pm 0.5^{\circ}$ error assigned is made from repeated measurements and taking the average. This is acceptable, first bearing in mind the accuracies feasibly attained in ancient times, and second that it does not alter our interpretation.

In azimuth and declination the precession, refraction, atmospheric extinction and proper motion are all accounted for from the astronomical software used. In fact the atmospheric refraction $(r)$, which bends rays of light downward, allows the star or Sun to be seen when it is in fact below the horizon. The corrected declination is - $r$, where $\mathrm{r}$ varies from $56^{\prime}$ for altitude $\mathrm{a}=-1^{\circ}$ to $36^{\prime} 36^{\prime \prime}$ for $\mathrm{a}=0^{\circ}$, decreasing rapidly as the angular altitude goes up by just a few degrees as in Delphi, Didyma and Hierapolis but not at Rhodes and Delos. Atmospheric extinction does not significantly affect the declination of a horizon point but can render stars invisible before they reach a low horizon, even though they are still in the line of sight. 
Another two applications, the Google Earth Compass Tool and Google Compass were applied for the calculation of the $\mathrm{Az}$ of the temple with an uncertainty $\pm 2^{\circ}$ taken from repeated measurements and compared with in situ values (in Rhodes and Delphi). Both these were used for declination and ancient sky map images, through astronomical software.

In the image taken from Google Earth a straight line is traced along the symmetry axis of the temple itself (with an uncertainty in overlapping $\pm 2^{\circ}$ ) and then extrapolated to the horizon towards the farthest and highest possible top point. Using the application for slope calculation we can actually see the relief of the landscape in front of the temple and following the straight line created we can also determine which is the highest point of the horizon (marked by an arrow in Fig. 3), the application also provides the altitude and distance that allow the calculation of the AAS via trigonometry all with a satisfactory accuracy.

Results are given in Table 1. Horizon panoramas are shown that explicitly indicate the star configuration with sunrise in the case studies. Both fieldwork and virtual work were used to compose the article. The first research work on the matter was centered in the measurement of the skyscape of the Temple at Delphi. In the case of the Delphic sanctuary both fieldwork with GPS and compass were used and then compared with software tools. (Google Earth, compass tools and other Google Earth applications) The same methodology was used at the Pythian Apollo temple in the Acropolis of Rhodes. The measurements in both temples allowed us to compare the accuracy of the remote sensing research and to reduce the possibility of error. The landscape of the other three temples was then researched by virtual means with a level of accuracy achieved by extrapolating the results taken from the comparative measurements in Delphi and Rhodes. At any rate earlier readings by other authors in

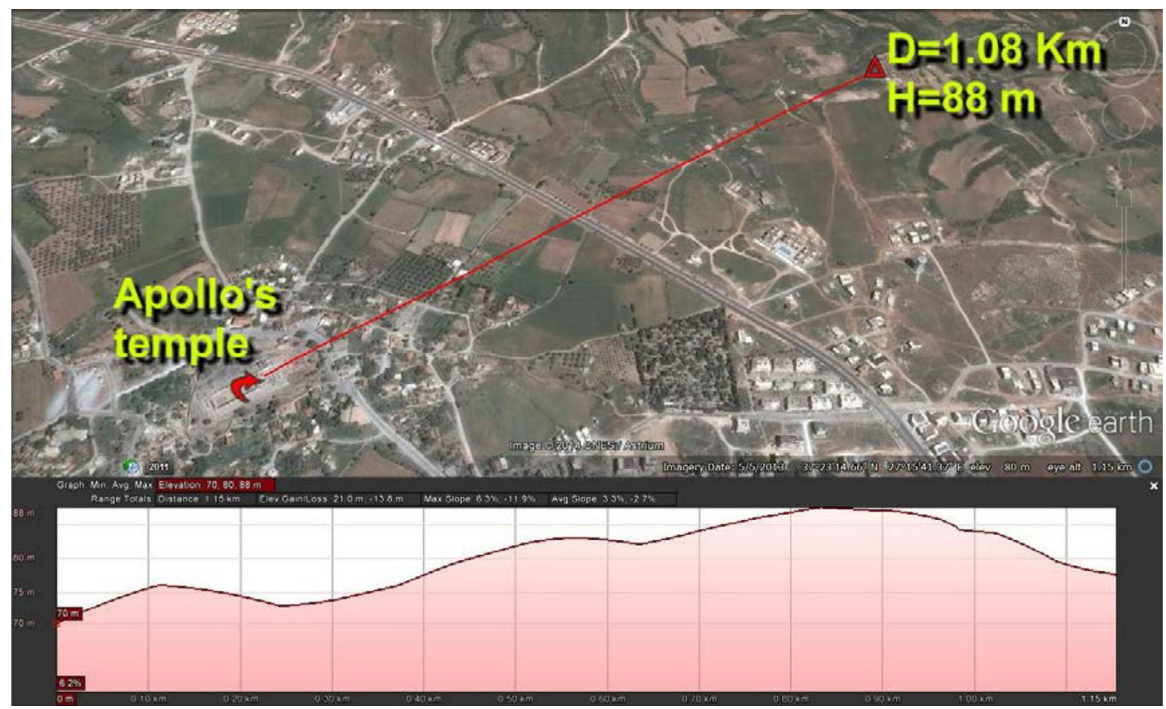

Fig. 3 The application for the AAS slope calculation applied at the temple of Didyma. The distance between temple and horizon peak along the extrapolation of the temple's axis is noted with the two arrows, while the relief landscape and the height is shown in the lower part 
Delos and Didyma agree within expected errors (standard deviation of the mean) to Google Earth estimations (see Table 1). This demonstration shows the practical use of remote sensing maps with satisfactory resolution, and the advantage of avoiding travel expenses and time.

$\mathrm{Az}$ and AAS measurements for Delphi and Rhodes were measured along any available straight undistorted side wall both foresight and back sight and take the average.

\section{Didyma}

The Great Temple of Apollo at Didyma was the most renowned Sanctuary and oracle of the ancient Greek world, after Delphi (Boustan and Reed 2004, pp 217-218; Raphals 2013, p 25). It dates from almost the same period, although it had a much more hazardous time when it was destroyed in $494 \mathrm{BC}$ by the Persians (Raphals 2013, p 25 note 15,156; Hdt. 1.46.2, 1.92.2). Didyma is connected to Delphi with respect its establishment.

Regarding the temple's architecture, most scholars having studied the temple of Apollo at Didyma agree that its unique architecture, consisting of this enclosure hiding the temple and oracle itself within huge walls, was aimed at the creation of a kind of underground adyton, a cultic place similar in function to that in Delphi.

An adyton is a sacred restricted area but this does not mean that it has to be found forcedly "underground". The oracular procedure, so well documented at Delphi, is unknown at Didyma and must be reconstructed on the basis of the temple's construction, but it appears that several features of Delphi were now adopted: a priestess [Iamblychus' (325-245 AD) profetis, in De mysteriis] and answers delivered in classical hexameters.

Our research on Didyma was conducted by means of Google earth maps for Azimuth (Az) and Angular Altitude of Skyline (AAS) via Google Earth (Fig. 3).

In the image taken from Google Earth a straight line is traced along the symmetry axis of the temple itself as described in the Measurements section above, and the raw extracted data given in Table 1.

Another application, the compass tool, can be applied for the calculation of the Az of the temple (Fig. 4). Both of these were used for declination and ancient sky map images, through astronomical software. The result was that Lyra rose at the exact $\mathrm{Az}$ of the temple by the sunrise of the winter solstice [Note-1]. The Az values from Google tools is $56^{\circ} \pm 1^{\circ}$ (façade) and the in situ values $56^{\circ} 25^{\prime}$ (Lirintzis and Vasileiou 2006a) Indeed the celestial event discussed and portrayed (see Fig. 8 below) occurs before dawn.

Yet there is a problem regarding the AAS. Although the orientation of the temple seemed to serve perfectly the reproduction of the same phenomena observed at Delphi, the altitude of the horizon lacking the mighty rock formations of the Delphic landscape was not high enough to "hinder" the constellations during wintertime. Therefore the myth of the god missing during winter at the land of the Hyperboreans could not be recreated. At first sight Didyma does not appear to have been built in order to follow the same astronomical guidelines used in Delphi. However, such a perfect orientation towards the Heliacal rising of the Lyra appears too much of a 


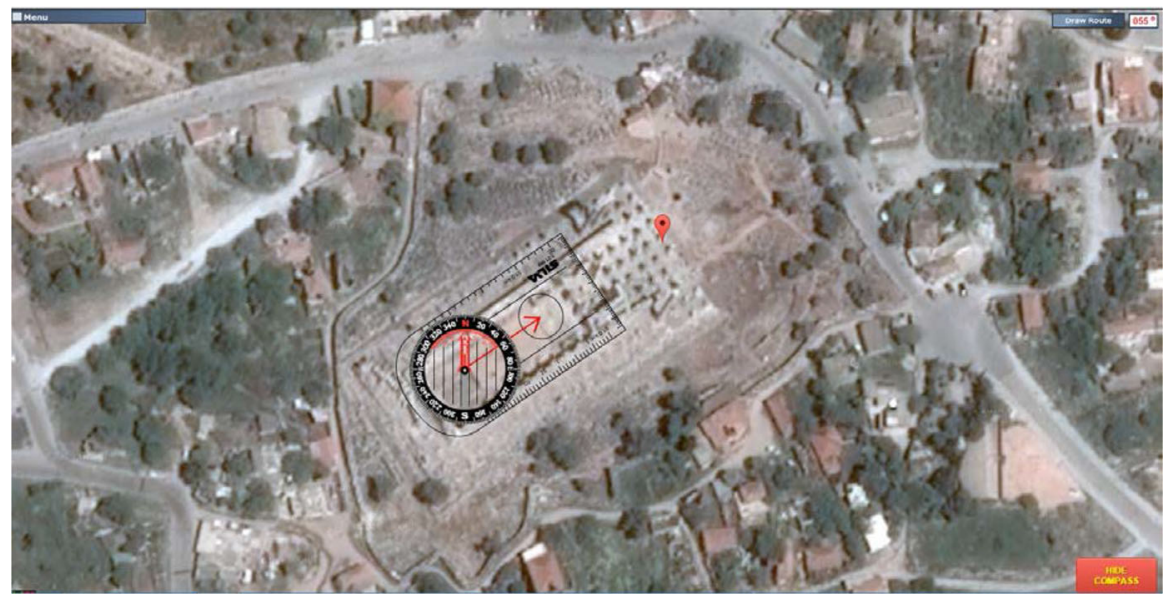

Fig. 4 The compass tool applied to Google Earth over the temple of Didyma (http:// www.googlecompass.com(c) Barcelona field studies centre S.L.)

coincidence and it was clearly made to fulfill some purpose. The solution to the puzzle comes when one observes the architecture of the temple.

The unique feature of Didyma's temple was that its small temple or naiskos was constructed within a huge enclosure of mighty walls whose height has been calculated to around 25-30 m (Figs. 5, 6) (Fontenrose 1988, p 38). ${ }^{2}$

Within this roofless inner court the above-mentioned tetrastyle temple could be found, surrounded by sacred laurels and a spring or well, all necessary elements to carry on the oracle practice whose foundations can still be seen at the remains of the temple today (Pollitt 1972, p 166).

The dark, descending causeways lead to the interior of the temple, clearly at a much lower level than the stylobate, making an adyton. The first question in that case could perfectly be, why was a court supposedly created to be a hidden, underground space left uncovered, open to the sky? All the descriptions we have from ancient sources speak of an aithrion (open court) and the archaeological research also seems to prove that the inner court of the temple was not covered at all. Certainly the hidden, obscure passages leading to this interior court created the impression of entering a sacred, hidden place, a kind of inner sanctum not reachable to everyone. That is in fact the meaning of an "adyton". Actually such places involved the aura of the most sacred place, where only very few people were allowed to enter, usually after following certain rites and only on certain occasions (Zacharia 2003, p 39).

The explanation for the unique architecture of the Great Apollo's temple at Didyma can be related to astronomical observation. Measurements from in situ maps, publication reports (Fontenrose 1988) and Google Earth images indicate that the orientation of the temple and the AAS created by the $\sim 25-30 \mathrm{~m}$ height of the

\footnotetext{
2 "the walls were about $25 \mathrm{~m}$ high including the podium [...] the podium about $5.2 \mathrm{~m}$. high..." (Fontenrose 1988).
} 


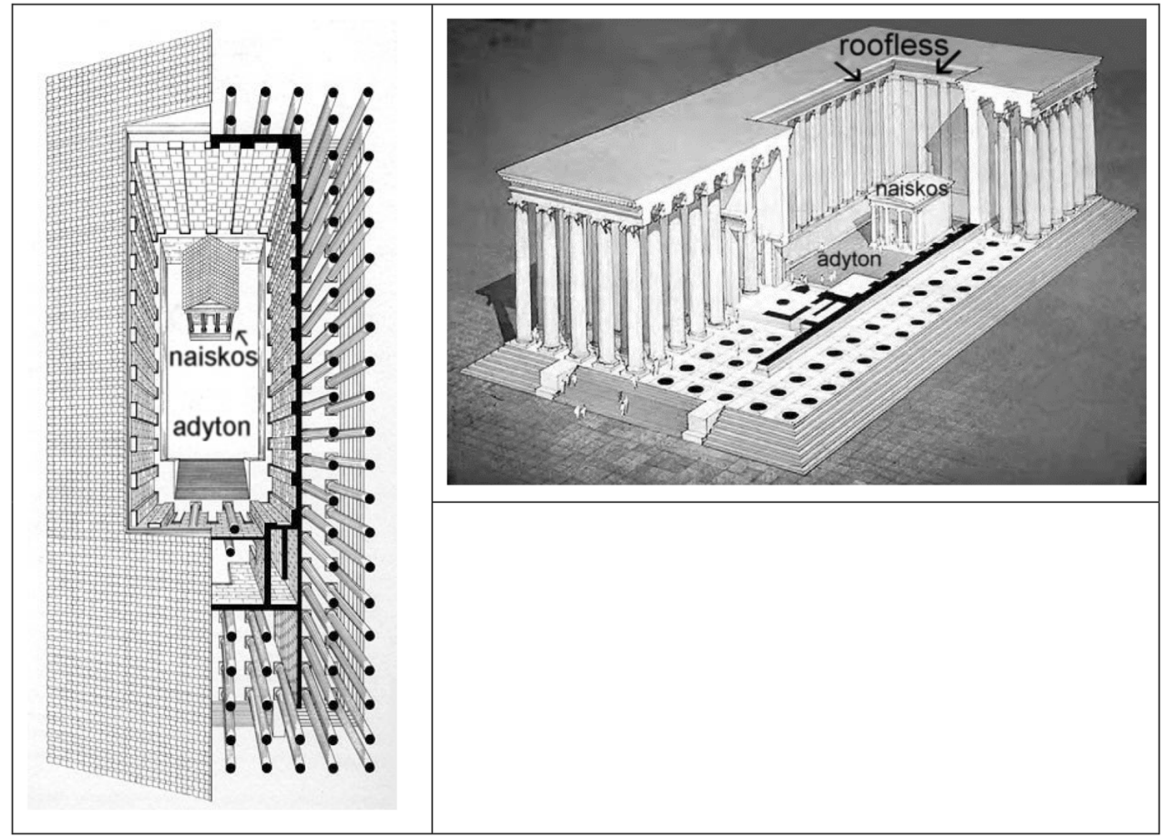

Fig. 5 Reconstruction and axonometric plan of the temple of Apollo $($ Academy Editions. Foundation of the Hellenic World (http://www.fhw.gr/choros/miletus/en/didima.php?submenu_top_id=0b)

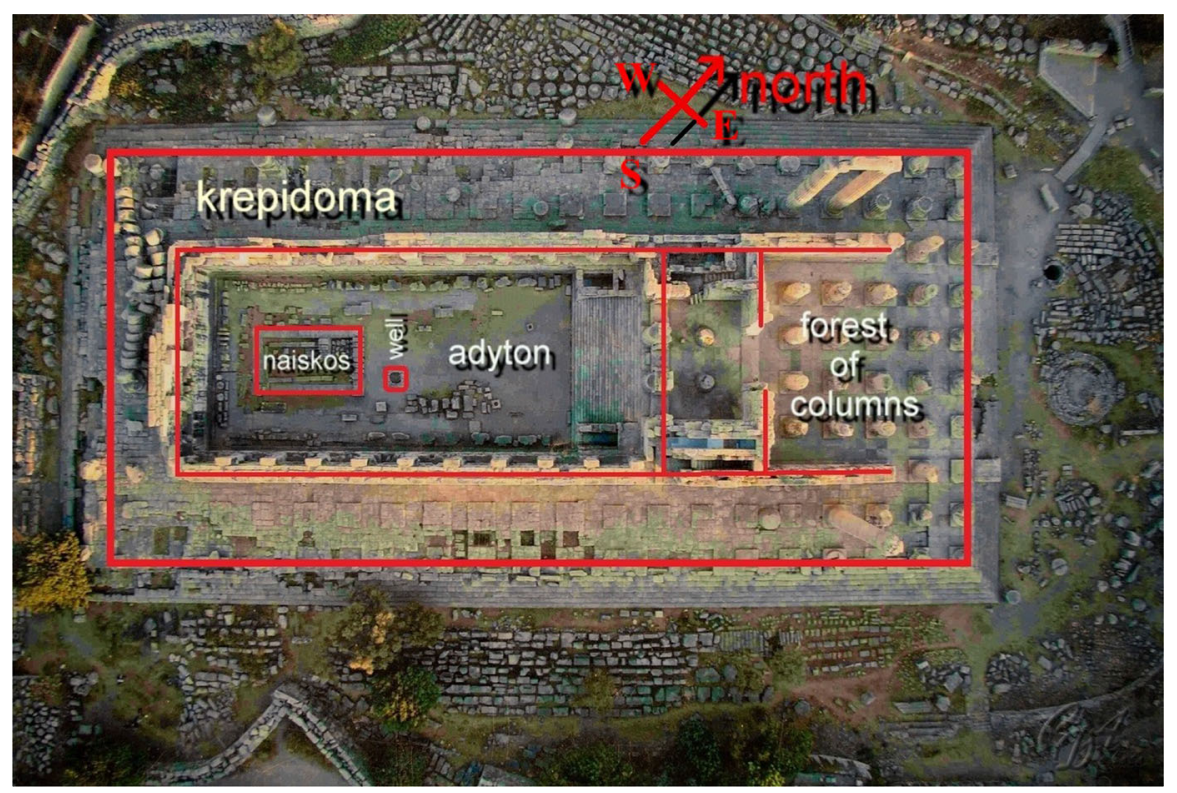

Fig. 6 Aerial view of the temple taken with Quickbird-2 via Apollomapping.com 


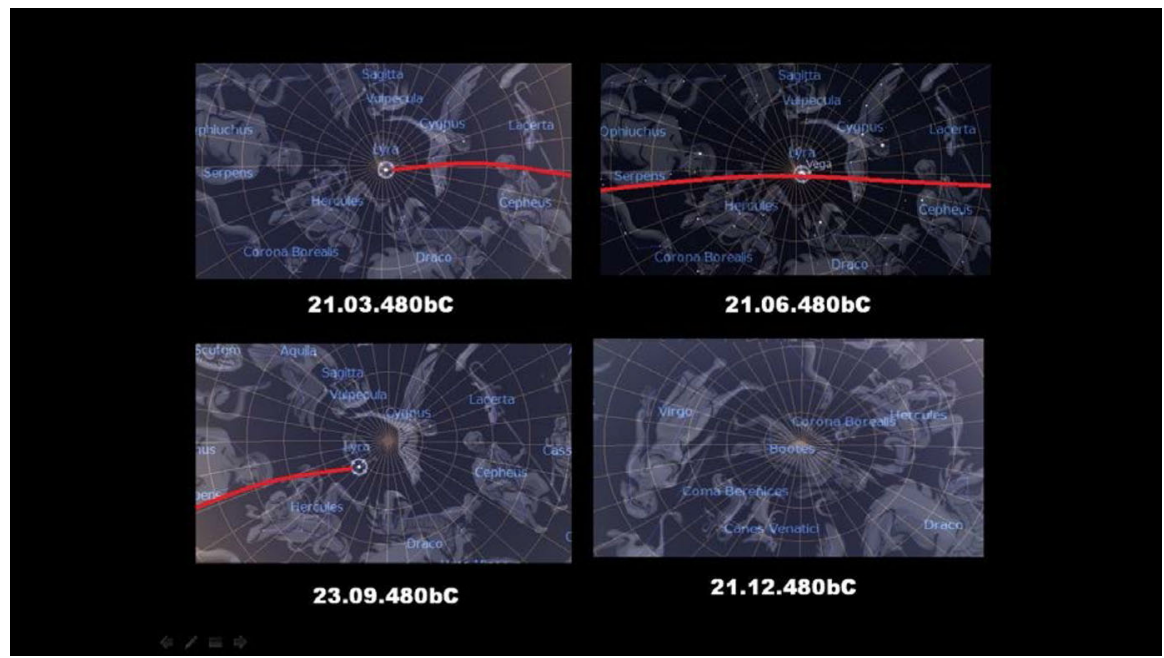

Fig. 7 Stellar cycle showing the seasonal appearance and "path" (in red) of the constellations over the Temple of Apollo at Didyma referring to the $480 \mathrm{BC}$ representative date for Didyma, as seen from inside the adyton. Outside the adyton the constellations appear similar to those in Delphi (Fig. 1) (colour figure online)

walls (or an angle $\sim 37^{\circ}$ from adyton in contrast to $4.06^{\circ} \pm 1^{\circ}$ outside the temple, see Fig. 8 below) served to reproduce the same effect of Apollo's related constellations (Lyra and Cygnus) "appearing" and "disappearing" from the sky according to the myth of his yearly trip to the land of the Hyperboreans. In a reconstruction of the path of both constellations over the temple of Didyma similar to the one we had for Delphi, the result and dates of the appearance and disappearance of the stars are exactly the same we observed in the Delphic sky (Fig. 7) and Table 1. The most important difference of course is the fact that in Delphi the "effect" is created by the natural landscape, while in Didyma it is artificially made by the construction of the huge enclosure of the temple's court.

Another structure possibly related to astronomical observation is the stair on the eastern side of the adyton or inner court. Those stairs actually did not lead to the entrance as it seems today. The inner NE wall of the adyton was still standing and the interior of the court was perfectly closed. That means that those stairs actually did not lead anywhere. Some scholars (Fontenrose 1988, p 38-39, Pollitt 1986, $\mathrm{p} 297$ ) point out that they could have some kind of cultic use related to the ceremony of omen-giving. Yet, they admit that actually their real purpose is not known. Accessibility remains a puzzle. This higher point of the interior court is the better spot for the observation of the constellations as it "hides" the first morning appearances of the Lyra during wintertime when the god is missing and Lyra should not be yet seen (Fig. 8) and allows the observance of the departure of the constellations at the western side of the temple by the sunset of the autumn equinox when the "departure" trip of the god begins. The AAS at Didyma is $4.06^{\circ} \pm 1^{\circ}$ and inside the Adyton is $37^{\circ} \pm 0.75^{\circ}$. In Delphi the effects of both occurrences are caused by the natural altitude of the mountains surrounding the temple; in winter 


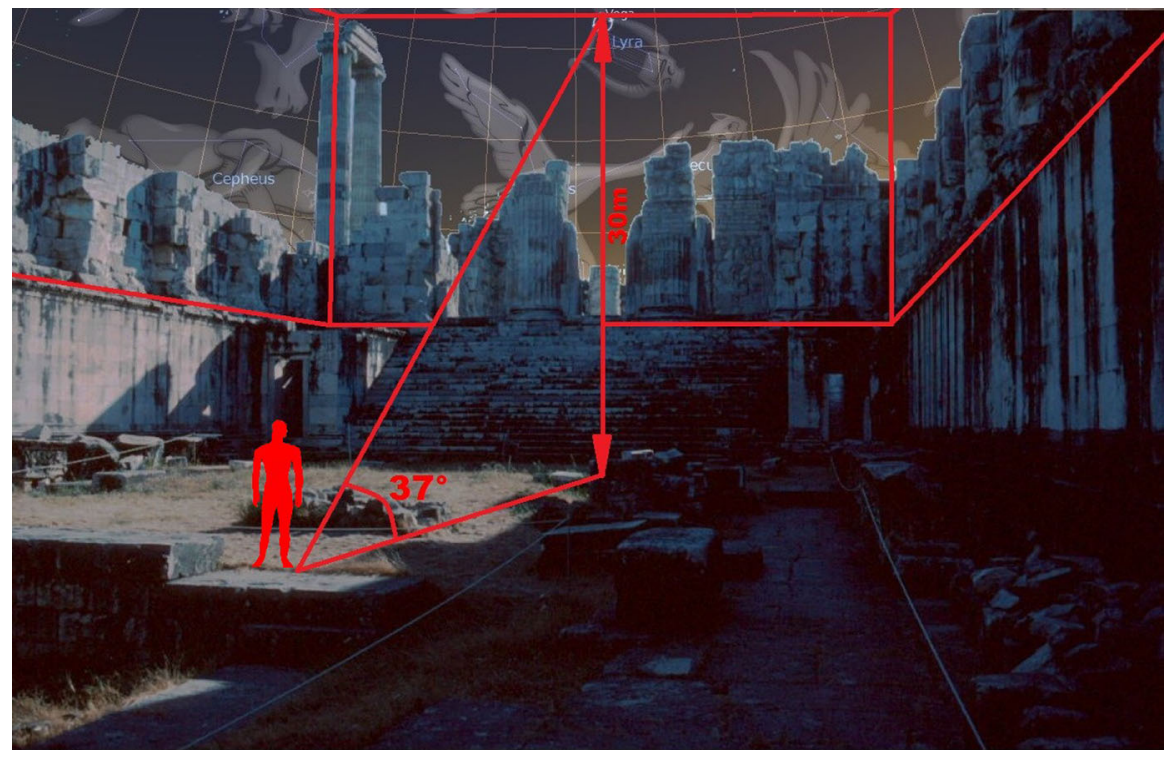

Fig. 8 Schematic heliacal rising of Lyra in the morning of the Winter Solstice above the top of the inner walls of the roofless adyton

months by the height of the mountains in front of the façade and the weather conditions, and in autumn by the lower AAS of the mountains at the back side of the temple that allows the constellations to be seen at sunset.

It is found that the Delphic astronomical phenomena with the two constellations appearing and disappearing at certain dates of the year could be observed at Didyma too.

An important fact found by archaeological research (Fontenrose 1988, pp. 106-107) is that the oldest remains of the archaic great temple are those of the naiskos or inner temple and the foundations of three of the great walls surrounding it. In fact the oldest and, maybe at the beginning, the only walls around the inner temple were the NE, NW and SW walls leaving "uncovered" the SE side of the temple facing the sunrise. That is exactly the same landscape that can be found at Delphi where the mountains surround the temple at the same cardinal points. At some period the enclosure of the temple was closed with another wall making an adyton.

In Hellenistic times, Asian oracles seemed to be more active than those in mainland Greece. This could be a possible explanation for the construction of our next example of Apollonian sanctuary and oracle built not so far from Didyma. It is the oracular temple-sanctuary of Apollo at Hierapolis, close to the modern site of Pamukkale in Turkey.

\section{Hierapolis}

In Hierapolis of Phrygia, as in Didyma and Delphi, there was an oracular shrine of Apollo. It was, however, founded several centuries later than the shrines in Didyma 
and Delphi. The sanctuary of Apollo had three temples (A, B and C), and all three were well established by the 1 st century AD (Semeraro 2008, p 117). The sanctuary is founded on a seismic crack which emits toxic (hydrocarbon) gases (D'Andria 2013, p 185).

The first traces of the cult in the Hierapolitan Apollo sanctuary are Hellenistic, and can probably be connected with the Seleucid foundation of the city in the third century BC (D'Andria 2003, p 9; Semeraro 2012, p 311). The same geophysical properties there as in Delphi had led to an early extensive cult of Kybele, the Great Mother goddess of mountains and caves and of birth, death and rebirth. Her cult area, in use perhaps as early as the seventh to sixth centuries BC (Piccardi and Masse 2007, p 98; Ritti 1985, p 137; 2006, p 132) has been found in connection with the newly discovered Plutonion (D'Andria 2013) of Hierapolis. Both cities are linked to the Hyperborean myth (Bridgman 2004, pp 20-21, 37; Richardson 2010, $\mathrm{p}$ 81). Although evidence is not conclusive on all points, and reservations should be made (Tullia Ritti, personal communication to A.N, 2014), temples A, B and C (Fig. 10b) may all have had an Apolline connection (Burrell 2004, pp 135-137; D'Andria 2013, p 188; Ritti 2003, p 188; Semeraro 2012, p 304), like they did in Delos.

The unique geological properties of the region probably contributed to the foundation of the city and its dedication to Apollo and his mantic abilities. Temples $\mathrm{A}$ and $\mathrm{C}$ are founded directly on the crack and their cults were of a mantic/oracular character (Semeraro 2012, p 305; 2008, p 117). Oracular traditions at the sanctuary must indeed have been strong, since the sanctuary and the oracle share the same astronomical pattern as those of Delphi and Didyma. Again, the AAS and Az of the sanctuary were calculated by means of remote sensing using the applications offered by the software of Google Earth (Figs. 9, 10a, b). Calculation of Az is made by the application of the compass tool, while the AAS is calculated from the cosinus of the altitude of the highest peak visible from the temple over the distance between them.

The orientation measurements and use of Stellarium indicated that in Hierapolis, too, Lyra was rising at the exact Az of the sanctuary at the sunrise of the winter solstice and that the same movements of "appearing" and "disappearing" of the constellations of Lyra and Cygnus could be observed from the sanctuary, just as from the temples of Delphi and Didyma (Fig. 11). The movements of "appearing" and "disappearing" may, as in Delphi, be linked with the Hyperborean myth, which depicts Apollo as disappearing (going north) as Dionysos reappears, and vice versa for the other half of the year. As such, the constellation functioned as a seasonable marker, visible all summer over the temples at night.

As temples $\mathrm{A}$ and $\mathrm{C}$ were built over an active fault line emanating hydrocarbon toxic gases, prophecying near or above the gas source, may have caused the priest or priestess to enter into a state of ecstasy (Fig. 10b). This is exactly the same geological condition found under the temple at Delphi. Quite possibly the architects of Hierapolis noticed the similar "sacred" conditions due to the particular geological characteristics of the area and following the already known path created through centuries of "oracle building"; they found that the proper orientation of the temple had to follow the pattern of the god "appearing" and "disappearing" with his Lyra and swans. 


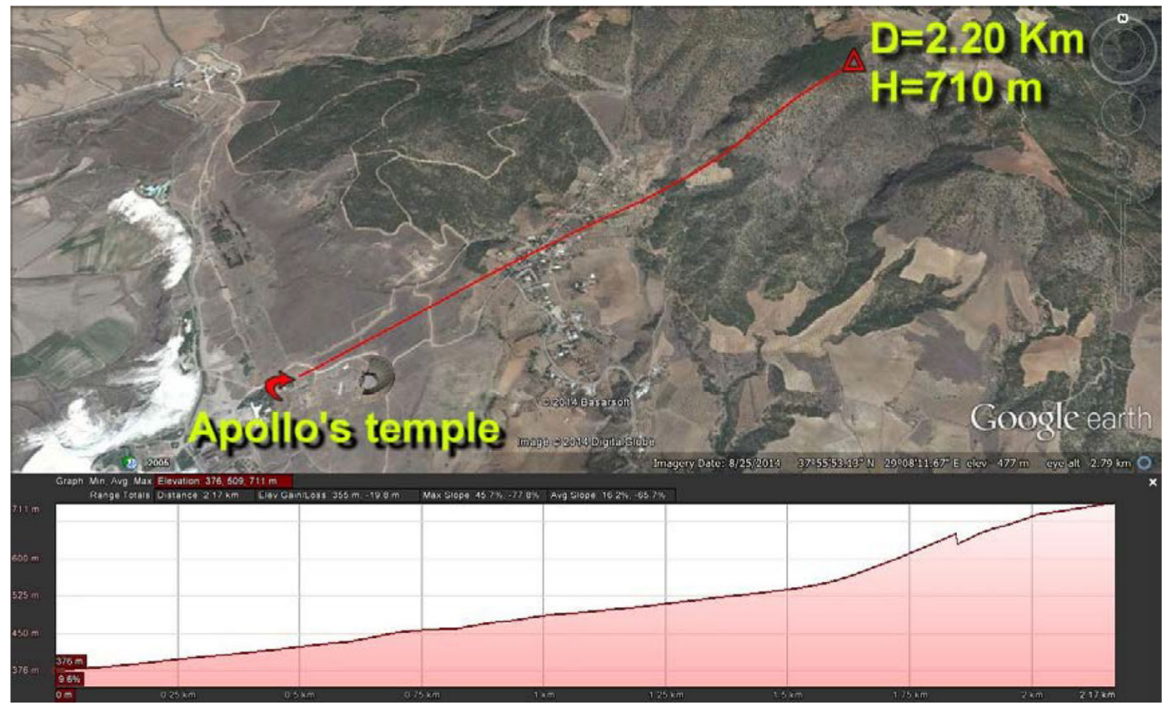

Fig. 9 AAS calculation applying Google Earth. Profile of the slope between the sanctuary and the highest point at the horizon

The temples were situated within an enclosure wall (peribolos) west of the south theatre of the city. The major difference from the other Apollonian temples of this study is that the entrance to the temples of Hierapolis is oriented SW in contrast to the NE entrance at Delphi and Didyma. Despite this difference the landscape in Hierapolis recalls the Delphic landscape, with the high horizon lines due to the mountains that surround the area. Moreover, a monumental triangular tomb, originally ca. 15 meters tall, situated exactly 0 (zero) degrees north of temple C, may well be a marker for the Hyperborean cult, indicating the direction north for Apollo on his leave for the Hyperborean at the Winter solstice (Fig. 12).

Having noticed the geological similarities between the areas of Delphi and Hierapolis, the founders of the shrine somehow may have associated the landscape to Apollo's will to reproduce the oracular functions of his main sanctuary in Delphi in this area of Asia Minor. Although the time gap constituted several centuries, the architects of the town certainly knew the astronomical phenomena they should have in mind when searching for the proper orientation of the temple-oracle. One interesting point is that the AAS of Hierapolis in winter cannot "hide" completely the constellations for the few moments of sunrise and sunset in order to create the effect of the god leaving for the Hyperboreans (Fig. 13). This was exactly the same for Delphi. Sources coming from Delphic experts like Plutarch, inform us that the weather conditions in the mountains were crucial for the correct function of the oracle and the calculation of the dates. The fact was that the cloudy winter mornings in the Delphic mountain landscape helped to hide the few minutes of visibility of Vega, the first star of the Lyra. Exactly the same phenomenon can be observed in Hierapolis, a town at a much more southern latitude than Delphi with warmer 


\section{a}

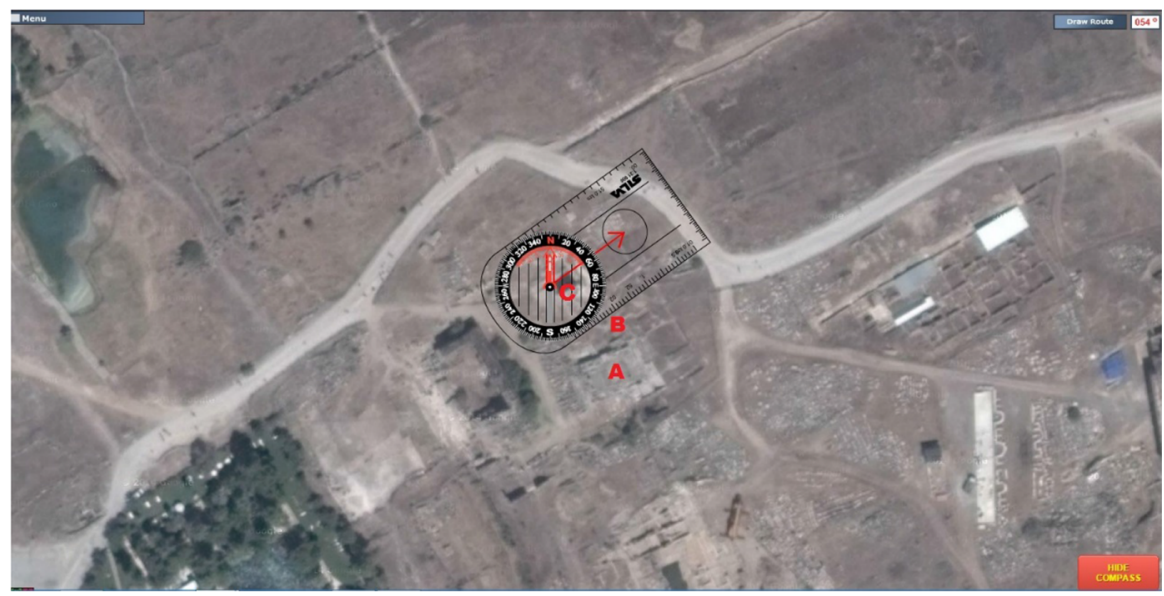

b

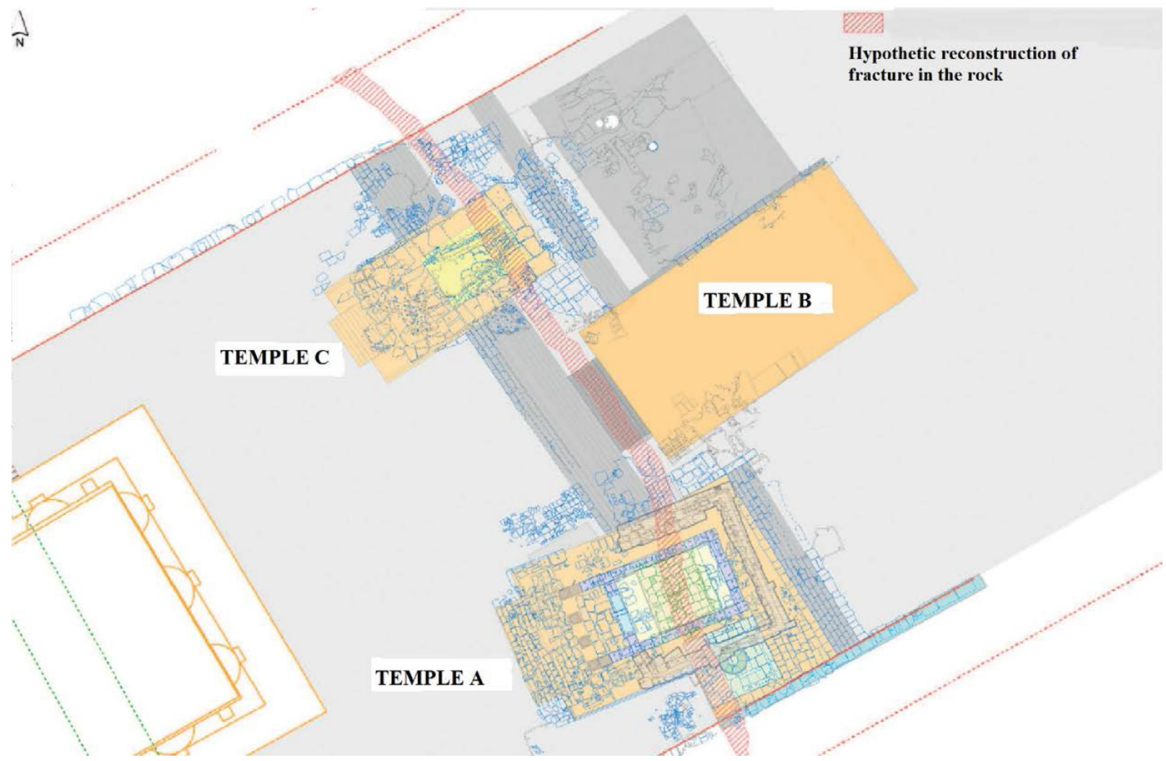

Fig. 10 a Compass tool used from the sanctuary of Hierapolis. b Plan of the temples in the sanctuary. The pink line shows the gaseous seismic fracture below "Edificio" A and C (Semeraro 2012, p 305, Fig. 21) (colour figure online)

weather, but still having heavy cloudy winters due to humidity from the hot springs together with the winter mountain landscape.

Overall, regarding geological settings, it seems that seismic faults in the Hellenic world had a connection with sacred sites. 


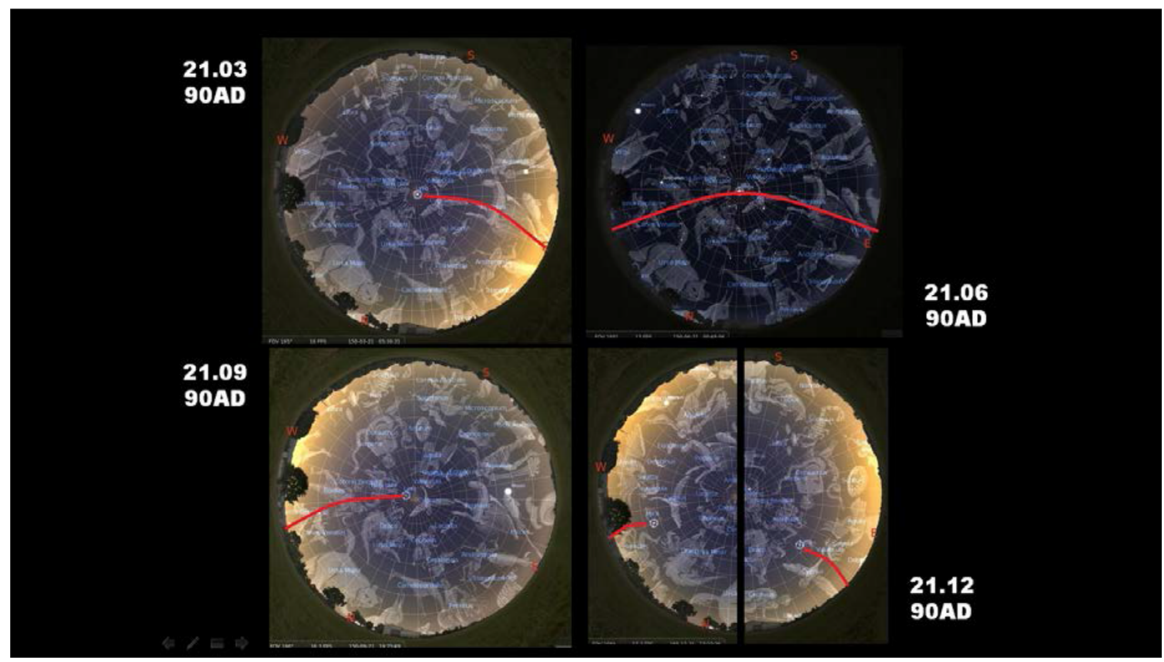

Fig. 11 The "path" (due to earth's rotation) of the constellations over the temple at Hierapolis

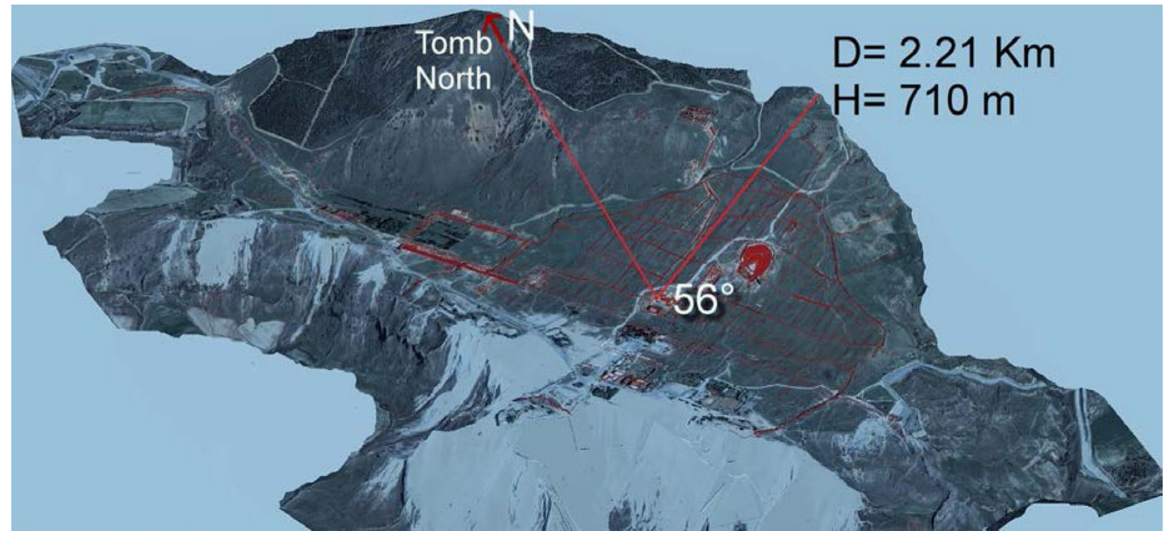

Fig. $123 D$ reconstruction of the mountain landscape of Hierapolis with its monumental buildings (D'Andria et al. 2008, with indication of tomb and geographical coordinates added by authors)

\section{Temples Without Oracular Function: Delos And Rhodes}

The Cycladic island of Delos was the birthplace of Apollo. The Great Apollo's Temple in Delos was also one of the most renowned sanctuaries in the Greek world. Its construction began in BC 476 and it is a peripteral construction in Doric order with its main entrance located on the west side.

The astronomical research regarding the orientation of the temples towards the Heliacal rising and setting of the constellations of Lyra and Cygnus showed that on Dec. 21st 475 BC, by sunrise, both constellations were already high in the sky and perfectly visible (Fig. 14). 


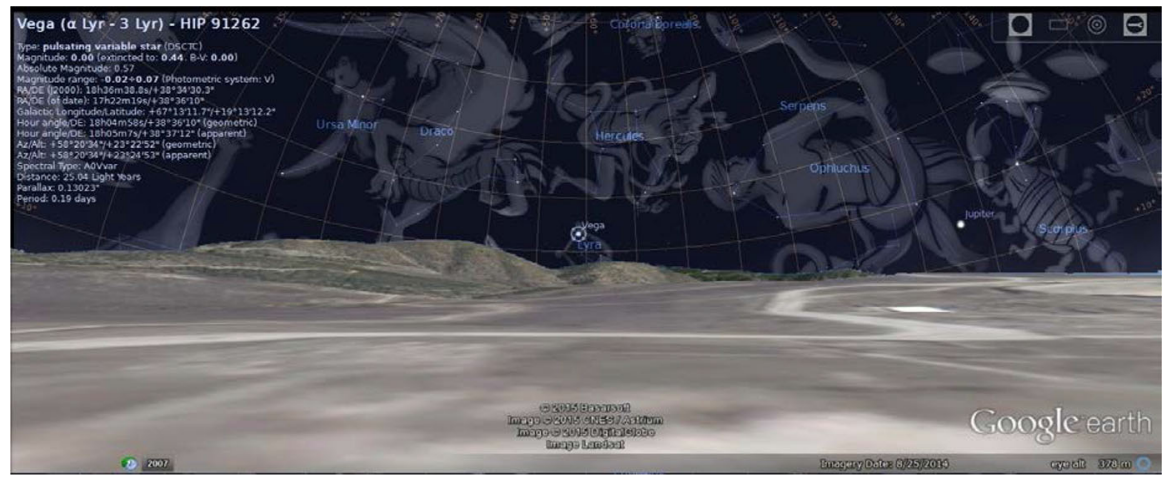

Fig. 13 Hierapolis: Vega at dawn $(5.50 \mathrm{am})$ of winter solstice $90 \mathrm{AD}$, from the rear of temple C

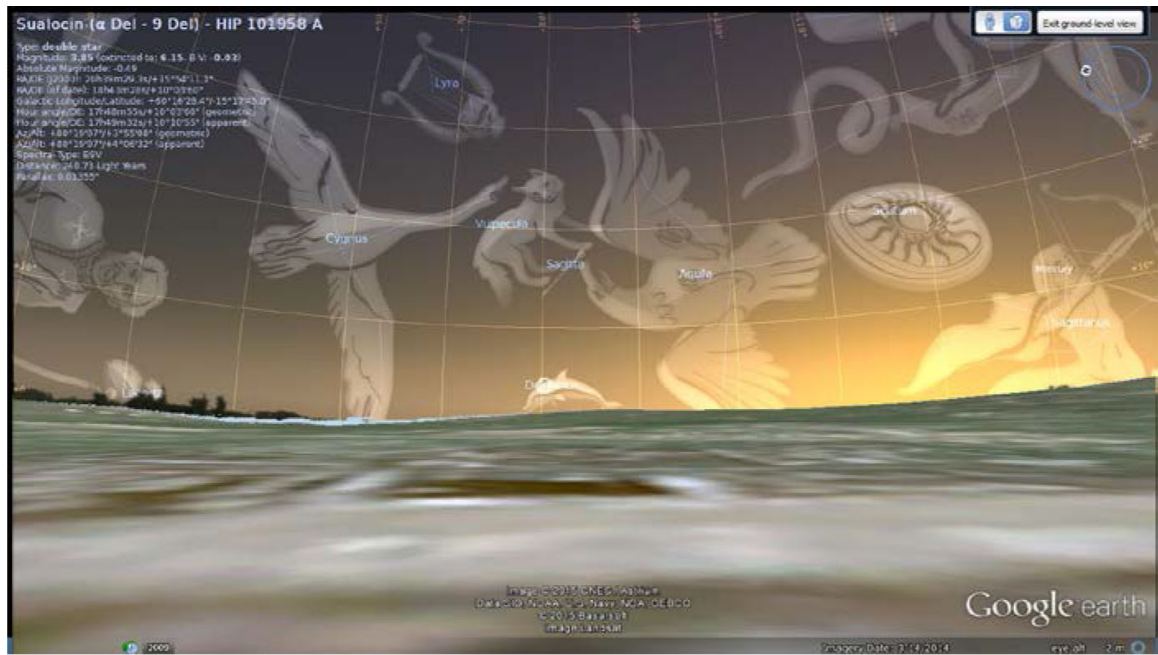

Fig. 14 The Delian sky by the sunrise of Dec. 21st 475 BC

Indeed the skyline of Delos is a rather different one; the horizon of the island by the Great Temple has a low AAS of $4.4^{\circ}$ (Fig. 15) and of course the weather conditions of the Cycladic winter offer many more possibilities of having cloudless nights allowing stargazing.

So it becomes clear that the Delian Temple did not follow the pattern of the god leaving for the Hyperboreans, since both of the constellations of Lyra and Cygnus were visible during the whole winter. For an azimuth of $83^{\circ}$ and low AAS in Delos the sun rises on 21st of September and the dolphin emerges on 21st of December. Obviously the dolphin (with magnitude $+4 \mathrm{~m}$ and the naked eye could see $\sim+6 \mathrm{~m}$ ) is faint and moreover during winter hard to see, so that it cannot be used comfortably as a time marker. 

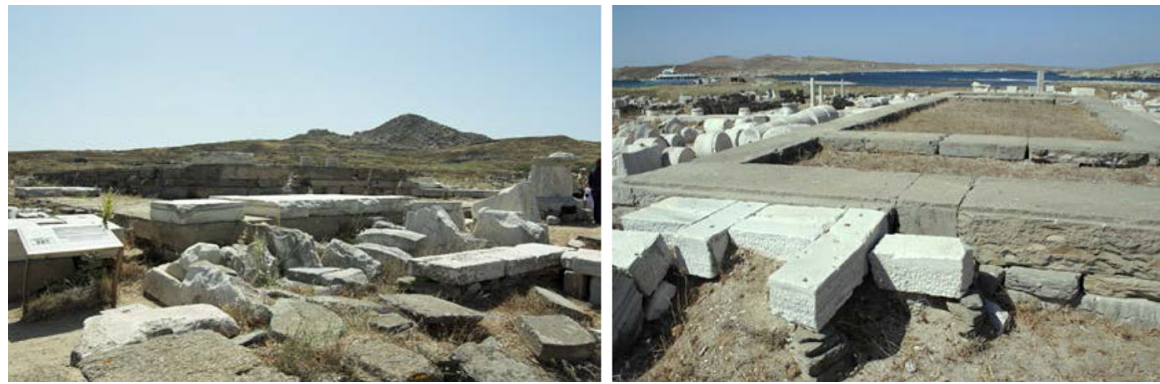

Fig. 15 Delian landscape and horizon from the Great Temple (from Tsakos 1998). The image on the left side shows the sacred mount Kynthos due east of the temple, and on the right side the western horizon of the temple

The Pythian Apollo temple is at the Acropolis of the city of Rhodes, the city which is securely dated, and this Temple is dated just after BC 408. It is a clear example of a Doric peripteral temple from the late Classical period with its main entrance towards the East (Rocco 1993).

As the critical seasonal period for checking the celestial pattern of the constellations is the winter, here the celestial sphere at the sunrise of the Winter Solstice gives a similar pattern to the Delian case. The low AAS allows the Lyra and Cygnus to be seen during the winter months, thus, the myth of Hyperborean Apollo "leaving" with his Lyre and swans could not be applied, since both constellations never really disappear from the Rhodian night, while the Temple's orientation is due east at the spring equinox (Fig. 16).

The main difference between Delos and Rhodes, and the other three examples studied, was the fact that neither the sanctuary at the sacred island nor the temple at the new city of Rhodes had any oracular function, and neither is the construction of the Delian or Rhodian temples related to any kind of fracture or seismic crack, natural sources of gas, or water springs, so closely related to the construction and function of the oracular sanctuaries of Apollo. Here the astronomical scenario does not reproduce the imagery of the hyperborean myth with the lyre and swans of Apollo being absent during the winter months. In Rhodes the sun rises along the entrance of the temple during equinoxes, a possible calendar point in relation to the deity's solar worship on the island.

\section{Discussion}

The use of Google Earth is a useful and powerful tool in certain instances, compared to in situ measurements, that aids astronomical orientation of ancient temples (Table 1). Google Earth is a very useful tool for a study of the historical areas (Pavelka et al. 2011), especially not easily accessible sites. It saves travel expenses, time and effort, too. Possible inaccuracies (distorted images, landscape topography) must be taken into account, and comparison with in situ measurements is necessary. Here, there appears a satisfactory agreement between in situ orientation 


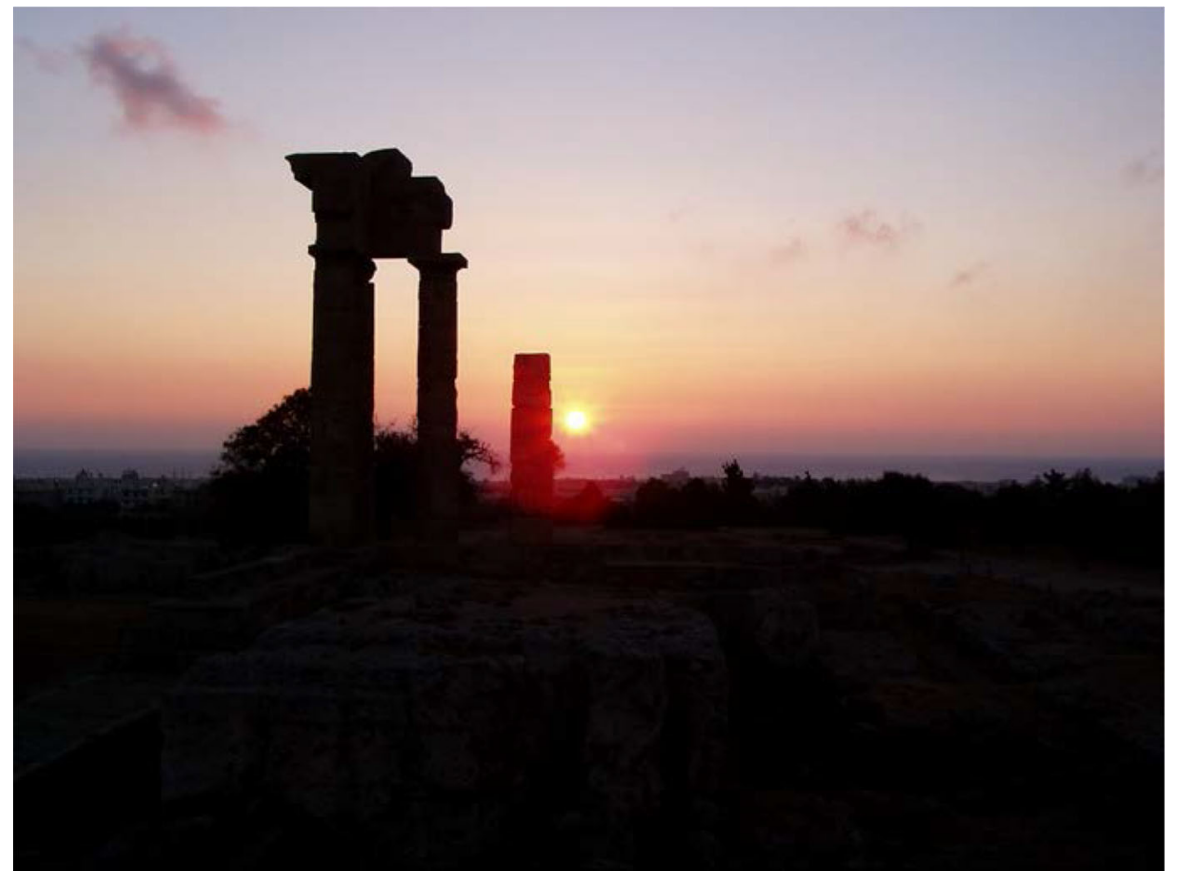

Fig. 16 The sunrise at spring equinox exactly in front of the entrance to the temple of Apollo at the Acropolis of Rhodes (taken by B.C.M.)

measurements and those computed through remote sensing images. This concordance is expected for distances between temples and horizon peak beyond a few hundred meters. Remote sensing techniques are becoming powerful tools for archaeologists in their discovery and exploration of ancient sites (Shaltout 2014). High resolution sensors (IKONOS with $1.0 \mathrm{~m}$ resolution, QuickBird with $0.61 \mathrm{~m}$ resolution and Geoeye- 1 with $0.50 \mathrm{~m}$ ) are possible substitutes for the classical aerial photos used for multi purposes, such as cartographics at large scales. Error in azimuth estimation (from Quickbird VHR, Google Earth (EYE-1) and in situ compass at Luxor varies between $\pm 0.5^{\circ}$ and $+3.5^{\circ}$ (Shaltout 2014).

From our work (Table 1) the difference between in situ and Google earth maps for $\mathrm{A}_{\mathrm{Z}}$ is around $1^{\circ}$, for geographical longitude and latitude less than $0.5^{\circ}$, and for AAS between $0.5^{\circ}$ and $2^{\circ}$. For the latter, larger deviations occur for small distances between temple and horizon. Other tests have shown images are offset/skewed by some meters $(5-15 \mathrm{~m})$ depending from the place on earth covered (Mather and Koch 2011). The geographical coordinates differ at the last digit of arc second, thus are insignificant for the purpose of orientation. These errors in our study do not alter the obtained landscape data projected to skyscape images in the past, making interpretation valid. All calculated images presented are reproducible with standard software. 
Three out of five of the temples are oracular sanctuaries of Apollo (Delphi, Didyma, Hierapolis) and they share a common property: the geomorphological and geological environment of the sites are linked directly to the regional geodynamical context of Greece, a region of tectonic turmoil throughout the Pleistocene and Holocene, characterized by distinct landscapes produced by the activity of active fault zones, intense seismicity, and in part, volcanism and hydrothermal activity (de Boer et al. 2001). In addition, the construction of temples were not topographically reinforced, as there was available space to choose the temple's deliberate style of foundation and thus orientation, making landscape a decisive factor for temple orientation, albeit at Didyma, the temple's architecture was designed to satisfy the desired effect (Scully 1962).

Lyra and Swan (Cygnus) followed by dolphin constellations, have a heliacal rising (strictly speaking this refers to a star, but here we broadly considered as 'heliacal rising' the successive emergence of constellations) and the appearance/ disappearance (low/high horizons in reality) from the respective night skies, along the apparent orbital path of the three temples of Delphi, Didyma and Hierapolis, make use of the natural landscape or reinforce the natural deficiency with an artificial horizon. The participation of sun, moon and stars in the establishment of a calendar in the apollonian oracles, as shown here and in past work (Liritzis and Castro 2013), leads one to consider a solar-lunar-astral calendar.

\section{Conclusion}

All of the five temples of Apollo at Delphi, Didyma, Hierapolis, Rhodes and Delos, were related to the cult of the god Apollo and functioned separately in both time and space. The novel finding is that, clearly, there was a relationship between oracular temples where the heliacal rising and virtual path of the constellations of the Lyra and Cygnus seemed to have been determinative at the time of choosing the proper orientation of the temples that were meant to become oracles as well. Oracular temples only, where special geological, landscape- and astronomical conditions were found, resulted in the rare combination that made those "god-inspired" landscapes so unique. Non-oracular temples are not associated to any special geological pattern and they do not follow this particular astronomical orientation, but seem to be orientated according to different reasons (deity's name day, celebrations, solar stands and/or northern lights).

\section{References}

Aveni, A.F. 2001. Skywatchers: A Revised and Updated Version of Skywatchers of Ancient Mexico. Austin: University of Texas Press.

Aveni, A.F. and A. Ammerman. 2001. Early Greek Astronomy in the Oral Tradition and the Search for Archaeological Correlates. Archaeoastronomy XVI: 83-97.

Belmonte. J. A. and Shaltout. M. 2009. In Search of Cosmic Order: Selected Essays on Egyptian Archaeoastronomy. Cairo: Supreme Council of Antiquities Press. 
Boustan, R.S. and A.Y. Reed 2004. Heavenly Realms and Earthly Realities in Late Antique Religions. Cambridge: Cambridge University Press.

Bridgman, T.P. 2004. Hyperboreans: Myth and History in Celtic-Hellenic Contacts. New York: Taylor and Francis.

Boutsikas, E. 2009. Placing Greek Temples: An archaeoastronomical study of the orientation of ancient Greek religious structures. Archaeoastronomy: The Journal of Astronomy in Culture, 21:4-19.

Burrell, B. 2004. Neokoroi: Greek Cities and Roman Emperors. Leiden: Brill.

D’Andria, F. 2003. Hierapolis di Frigia (Pamukkale): Guida Archeologica. Istanbul: Ege Yayinlari.

D'Andria, F. et al. (editors) 2008 Atlante di Hierapolis di Frigia. Istanbul. Ege Yayinlari.

D’Andria, F. 2013. Il Ploutonion a Hierapolis di Frigia. Istanbuler Mitteilungen 63:157-217.

De Boer, J.Z., J.R. Hale and J. Chanton. 2001. New Evidence for the Geological Origins of the Ancient Delphic Oracle (Greece). Geology 29: 707-710.

Dinsmoor, W.B. 1939. Archaeology and Astronomy. In: Proceedings of the American Philosophical Society 80: 95-173.

Dolansky, F. 2011. Celebrating the Saturnalia: Religious Ritual and Roman Domestic Life. In: $A$ Companion to Families in the Greek and Roman Worlds, ed. Beryl Rawson. Chichester: WileyBlackwell, 484.

Flacelier, R. 1938. Le Fonctionnement de l'Oracle de Delphes au Temps de Plutarque. Etudes Archeologiques Publiees par les Annales de l'Ecole des Hautes Etudes de Gant 11: 69-73.

Fontenrose, J. 1980. Python: a Study of Delphic Myth and its Origins. Berkeley: University of California Press.

Fontenrose, J. 1988. Didyma: Apollo's Oracle, Cult and Companions. Los Angeles: University of California Press.

Hawkins, G.S. and S.K. Rosenthal. 1967. 5,000 and 10,000-year star catalogs. Smithsonian Contributions to Astrophysics 10(2): 141-179.

Henriksson, G. and M. Blomberg. 1996. Evidence for Minoan Astronomical Observations from the Peak Sanctuaries on Petsophas and Traostalos. Opuscula Atheniensia XXI: 99-114.

Henriksson, G. and M. Blomberg. 2011. The Evidence from Knossos on the Minoan Calendar. Mediterranean Archaeology and Archaeometry 11 (1): 59-68.

Iwaniszeswki S. 2001 Time and space in social systems - further issues for theoretical archaeoastronomy in Clive Ruggles, Frank Prendergast and Tom Ray: Astronomy, Cosmology and landscape: Proceedings of the SEAC 98 Meeting, Dublin. Ocarina books. pp.: 1-7.

Klokočík J. Kostelecký J. and Pavelka, K. 2011. Google Earth: Inspiration and Instrument for the Study of Ancient Civilizations. Geoinformatics FCE CTU 6 (6) : 193-210. http://geoinformatics.fsv.cvut. cz (accessed 11 Oct 2015).

Krupp E.C. 2003 Echoes of the ancient skies. New York. Dover.

Leclerc, Y. 2008. La Notion d'Espace Souterrain dans les Temples Oraculaires d'Apollon. Arkeoloji Dergisi 12: 117-128.

Liritzis, I. and B. Castro. 2013. Delphi and Cosmovision: Apollo's Absence at the Land of the Hyperboreans and the Time for Consulting the Oracle. Journal of Astronomical History and Heritage 16 (2): 184-206.

Liritzis. I. and Vassiliou. H. 2002. Astronomical orientations of ancient temples at Rhodes and Attica with a tentative interpretation. Mediterranean Archaeology \& Archaeometry, vol.2. no.1. 69-79.

Liritzis, I. and Vassiliou H. 2003. Archaeoastronomical Orientation of Seven Significant Ancient Hellenic Temples. Archaeoastronomy International 17: 94-100.

Liritzis I. and Vassiliou H. 2006a. Were Greek temples orientated towards the aurorae? Astronomy \& Geophysics. Feb.2006. vol.47, 2, pp.1.14-1.18.

Liritzis. I and Vassiliou. H. 2006b. Highligting New Archaeoastronomical results from Greece (prehistoric, classical and Byzantine temples). In: Lights and Shadows in Cultural Astronomy.

Magli G. 2009. Mysteries and discoveries of archaeoastronomy. Copernicus Books, Praxis publishing.

Magli G. 2013. Architecture, astronomy and sacred landscape in ancient Egypt. Cambridge University Press. New York, p.25-30.

Mather, P and M. Koch. 2011. Computer Processing of Remotely-Sensed Images: An Introduction. (Google eBook), 4th edn. Chichester: Wiley Blackwell.

Nissen, H. 1906-10. Orientation, Studien zur Geschichte der Religion. Berlin: Weidmann.

Pantazis, et al. 2009. The Orientation of Delos' Monuments. Mediterranean Archaeology and Archaeometry 9 (1): 55-68. 
Papathanassiou, M and Hoskin M. 1994. Orientations of the Greek Temples on Corfu. Journal for the History of Astronomy 25 (2): 111-114.

Penrose, F.C. 1893. On the results of an examination on the orientation of a number of Greek Temples, with a view to connect these angles with the amplitudes of certain stars at the time these temples were founded, and an endeavour to derive there from the dates of their foundation by consideration of the changes produced upon the right ascension and declination of the stars by the precession of the equinoxes. Philosophical Transactions of the Royal Society of London (A) 184: 805-834.

Piccardi, L. and W.B. Masse. 2007. Myth and Geology. Geological Society.

Pollitt, J. J. 1972 Art and Experience in Classical Greece. Cambridge University Press.

Pollitt, J. J. 1986. Art in the Hellenistic Age. Cambridge: Cambridge University Press.

Raphals, L. 2013. Divination and Prediction in Early China and Ancient Greece. Cambridge: Cambridge University Press.

Richardson, N. 2010. Three Homeric Hymns: To Apollo, Hermes, and Aphrodite. Cambridge: Cambridge University Press.

Ritti, T. 1985. Fonti Letterarie ed Epigrafiche. Roma: G. Bretschneider.

Ritti, T. 2003. La Neocoria di Hierapolis di Frigia. In: Epigraphica: Atti delle giornate di studio di Roma e di Atene in memoria di Margherita Guarducci (1902-1999), 177-215. Rome: Quasar.

Ritti, T. 2006. Guida Epigrafica a Hierapolis di Frigia (Pamukkale). Missione Archeologica Italiana a Hierapolis. Istanbul: Ege Yayinlari.

Rocco, G. 1993. La Cita di Rodi. L’Acropoli. Il Tempio di Apollo Pizio. In: La Presenza Italiana nel Dodecaneso tra il 1912 e il 1948, a cura di Monica Livadiotti e Giorgio Rocco. Scuola Arceologica Italiana di Atene, 12-17.

Ruggles C. 1999 Astronomy in Prehistoric Britain and Ireland. Yale University Press.

Ruggles C. (Editor-in-Chief) 2014 Handbook of Archaeoastronomy and Ethnoastronomy (3 volumes). Springer.

Scully, V. 1962. The Earth, the Temple and the Gods. New Haven: Yale University Press.

Semeraro, G. 2008. Santuario di Apollo. In: Hierapolis Di Frigia II: Atlante Di Hierapolis Di Frigia, eds. F. D’Andria, G. Scardozzi and A. Spanò, 117. Istanbul: Ege Yayinevi.

Semeraro, G. 2012. Ricerche nel Santuario di Apollo. In: Hierapolis di Frigia V, Le attività delle campagne di scavo e restauro 2004-2006, eds. F. D'Andria, M. P. Caggia and T. Ismaelli, 293-324. Ege Yayinlari Istanbul.

Shaltout, M. 2014. Studying the Orientations of Luxor Ancient Egyptian Temples Using QuickBird Images. Journal of Earth Science and Engineering 4: 194-210.

Shaw, Joseph W. 1977. The Orientation of the Minoan Palaces. Antichita Cretesi (Catania) I, 47-59.

Tsakos, K. 1998. Delos - Mykonos, a Historical and Archaeological Guide. Athens: Ed. Esperos.

Zacharia, K. 2003. Converging Truths: Euripides' Ion and the Athenian Quest for Self-Definition. Leiden: Brill.

Belen Martin Castro with initial BA studies in Saragoza University Spain, has a BA in Archaeology, Dept of Mediterranean Studies, University of the Aegean and holds an MA in Egyptology.

Ioannis Liritzis is professor of natural sciences-archaeometry in the Dept of Mediterranean Studies, University of the Aegean, Rhodes, Greece and Director \& founder of Lab of Archaeometry. His research and educational interests are in natural sciences applied to cultural heritage, archaeoenvironment, interdisciplinary studies in arts, humanities, new technologies and physical sciences (www.liritzis.gr; http://dms.aegean.gr/en/faculty-members/ioannis-liritzis).

Anne Nyquist has a BA in history, MA in Archaeology and is currently PhD cand in Archaeology at the University of Oslo, Norway. 